Abbreviated Key Title: Sch J Med Case Rep

ISSN 2347-9507 (Print) | ISSN 2347-6559 (Online)

Journal homepage: https://saspublishers.com/sjmcr/

\title{
Facial Botriocytoma: Post Trauatism by Cow Horn in A Young Patient
}

N. Belhaj ${ }^{1 *}$, I. Boumendil ${ }^{1}$, H. Rahim ${ }^{1}$, H. Ait Taleb Oumhand ${ }^{1}$, S. Nitassi ${ }^{2}$, A. Oujilal ${ }^{2}$, R. Bencheikh ${ }^{2}$, M. A. Benbouzid $^{2}$, L. Essakalli ${ }^{2}$

${ }^{1}$ Resident Physician in Otorhinolaryngology, Department of Otorhinolaryngology, Head and Neck Surgery, Ibn Sina University Hospital, Rabat, Morocco

${ }^{2}$ Professor of Otorhinolaryngology, Department of Otorhinolaryngology, Head and Neck Surgery, Ibn Sina University Hospital, Rabat, Morocco

${ }^{3}$ Faculty of Medicine and Pharmacy of Rabat, Mohammed V University, Rabat, Morocco

DOI: $\underline{10.36347 / \text { simcr.2020.v08i10.016 }}$

| Received: 13.09.2020 | Accepted: 20.09.2020 | Published: 29.10.2020

*Corresponding author: Belhaj Najoua

Abstract

Case Report

Facial botriocytoma is a benign skin tumor; it is a very common conjunctive-vascular lesion whose starting point is often a small inflammatory wound. Initial skin trauma is often found. Surgical exeresis must remove the lesion completely with often healthy skin safety margins.in this work we report the case of young patient who presente facial botriocytoma one day post traumatic by cow horn.

Keywords: Botriocytoma, benign skin tumor.

Copyright $(\mathcal{2 0 2 0}$ The Author(s): This is an open-access article distributed under the terms of the Creative Commons Attribution 4.0 International License (CC BY-NC 4.0) which permits unrestricted use, distribution, and reproduction in any medium for non-commercial use provided the original author and source are credited.

\section{INTRODUCTION}

Botiomycoma, or pyogenic granuloma, is a benign inflammatory vascular tumor of the skin or mucous membranes, often secondary to minimal trauma.we report in this work the case of a 30-year-old patient one day post-traumatic by cow horn.

\section{CASE Report}

This is a 30-year-old patient with no significant pathological history, living in a rural area who has suffered a cow horn trauma at the right narinar furrow level, one day after the patient presents the appearance of a shiny, painless erythematous red nodule, which gradually grows in three weeks to reach $02 \mathrm{~cm}$ in diameter. It is sessile and crusty, the patient before the gradual increase in facial mass, she consulted in the emergency room, she benefited from a biopsy exèrese under local anesthesia, the evolution was good and no sign of local recurrence (Figure-1).

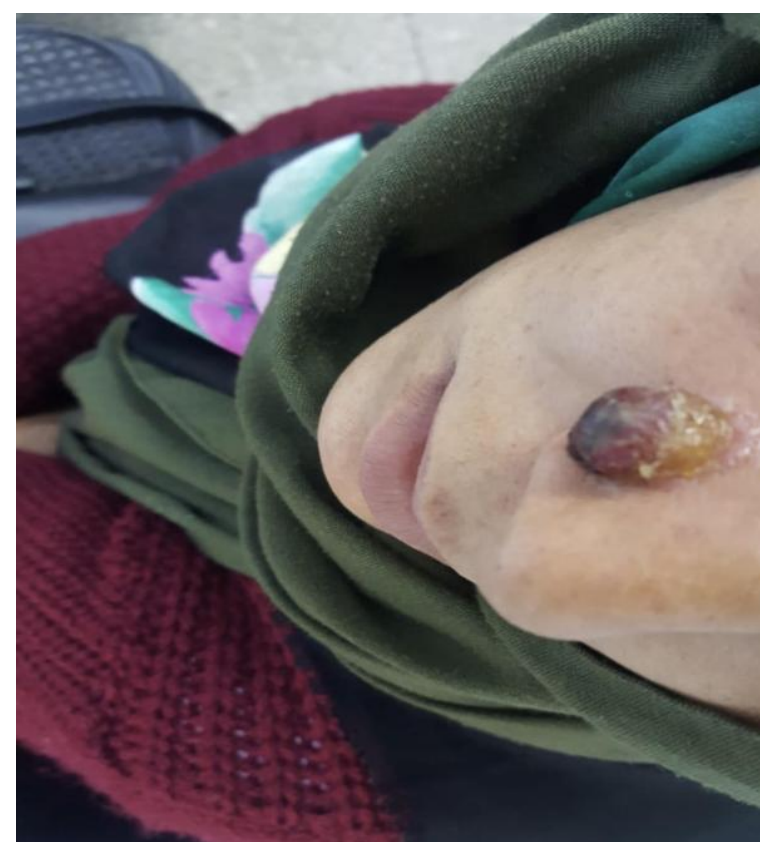

Fig-1: Image of the facial lesion before the surgical procedure 


\section{DiscuSSION}

Skin tumours (or lesions) are spots or growths of the skin of varying size, shape and colour. They can be found on the entire face or body. Each cell type contained in the skin is able to turn into a benign or malignant tumor; there are therefore a large number of skin tumours, ranging from the simple "mole" to the very rare tumour. They may appear during life or be present from birth $[1,2]$

Botryocitoma, also known as pyogenic granuloma, is a benign vascular tumour whose pathophysiology remains unexplained; it is a very common conjunctive-vascular lesion whose starting point is often a small inflammatory wound. It corresponds to an abnormal and inflammatory endothelial-cap proliferation that prevents the epithelialization of this scar. These tumours are usually small ( 5 to $10 \mathrm{~mm}$ ), unique and are of interest to the entire skin or mucous tegument but predominate in the acrale regions (peri-ungueal). The presence of a collar at the foot of the lesion is highly evocative and differentiates it from an infectious collection. Initial skin trauma is often found (soreness, repeated rubbing, recent surgery). Pregnancy and certain medications (isotretinoin, doxetaxel, indinavir, ciclosporin or lamivudine) promote the appearance of these lesions. This lesion, which is highly vascularized, bleeds easily on contact and recurs in the event of incomplete exeresis [2-5].

Surgical exeresis must remove the lesion completely with often healthy skin safety margins. A histological analysis of the lesion is systematic because only this examination can confirm the benign or malignant nature of the lesion $[1,2]$.

The invasive, poorly tolerated and scarring nature of the reference surgical treatment and other therapeutics (curetage, electrocoagulation, silver nitrate) poses a real problem in the female population especially when the location is facial. The Yag long pulse laser is better tolerated. The only topical treatment used was 6. poorly tolerated and inconsistent efficacy imiquimod. Timolol, a non-cardioselective beta-blocker, is available as a gel and eye drops at $0.5 \%$ for ophthalmological indications. It is known for its effectiveness in the treatment of hemangiomas. The pathophysiological hypothesis is that it causes vasoconstriction, inhibition of angiogenic growth factors and cellular apoptosis leading to the involution of the lesion. The literature reports several pediatric cases of unique botryomycomes successfully treated with timolol. The efficacy of the latter and its perfect tolerance reinforce the hypothesis that it may have its place in the therapeutic of botryocitoms of all types [2, 4].

\section{CONCLUSION}

Botriocytoma is a benign vascular tumour developed most often in the skin following minimal trauma, whose surgical erese remains among the best therapeutic attitudes.

\section{REFERENCES}

1. Girardot AC, Peyrony O, Verrat A, Fontaine JP. Botryomycome: soyez prudent, n'y touchez pas. Ann. Fr. Med. Urgence. 2014 May 1;4:189.

2. Wauters O, Sabatiello M, Nikkels-Tassoudji N. Le botryomycome. Ann Dermatol Venereol, 2010; 137:238-42.

3. Orgeolet L, Acquitter M, Fleuret C, Staroz F, Plantin P. Botryomycomes multiples récidivants traités par timolol topique. InAnnales de Dermatologie et de Vénéréologie 2016 Dec 1 (Vol. 143, No. 12, pp. S308-S309). Elsevier Masson.

4. Wauters O, Sabatiello M, Nikkels-Tassoudji N, Choffray A, Richert B, Piérard GE, Nikkels AF. Le botryomycome. InAnnales de dermatologie et de vénéréologie 2010 Mar (Vol. 137, No. 3, pp. 238-242).

5. Guichard S. Chirurgie des tumeurs cutanées. Encycl Méd Chir, Techniques chirurgicalesChirurgie plastique reconstructrice et esthétique. 1999;1999:45-140. 